\title{
A Study on Engineering Practice Teaching System Under the Credit System of Local Universities
}

\author{
Bo Jiang* \\ School of Intelligent Manufacturing, Jianghan University, Wuhan, China \\ *Corresponding author. Email: Jiangbo_2011@sina.com

\begin{abstract}
Under the background of credit system, it is imperative to study how to establish the practice teaching mode in local universities, especially the practice teaching system for engineering majors. In combination with reform of credit system, the conception of experiment teaching credit system has been proposed in this paper, which is of practical of their independent innovation quality.
\end{abstract} \\ significance to the cultivation of practical ability of engineering students from local universities and to the improvement
}

Keywords: Local universities, Credit system, Engineering practice.

\section{INTRODUCTION}

The credit system is a kind of teaching management system where students' academic completion status is measured with credit as measuring unit. From the perspective of domestic universities where credit system is implemented, most of curriculum setup, professional structure, teaching management system and other aspects of their engineering practice teaching cannot be targeted to highlight practice or innovation, the mode of cultivating talents is inclined to the research of theoretical learning; however, local universities mainly aim to cultivate high-level application-oriented and practical talents who will serve local economic construction, and the emphasis in their engineering practice teaching is to cultivate students' self-determined and innovative learning and to make them constantly create new technologies [1]. At present, traditional school year system is adopted in most local universities, with fixed learning period and unified cultivation plan, it is difficult for this traditional cultivation model to ensure the development of students' individuality and creativity, especially, this system is unable to meet the needs of engineering students' requirements on learning knowledge independently and innovatively. In this case, it is imperative to study how to adopt the teaching management system of credit system, so as to realize the diversified and personalized cultivation of talents, and to establish the practice teaching mode in local universities under new situation of credit system, especially the practice teaching system for engineering majors.

\section{PROBLEM OF PRACTICE TEACHING IN LOCAL UNIVERSITIES UNDER CREDIT SYSTEM}

Local universities mainly undertake the task of cultivating a large number of talents for local economic construction and social development, serving regional economy and society, and promoting the comprehensive construction of a well-off society, and the cultivation of engineering students is mainly to provide a large number of high-level application-oriented and practical talents for local industrial construction. Therefore, under the credit system environment, how to correctly offer relevant majors, to set up curriculum system and to form a perfect practice teaching system is particularly important [2]. Based on the above background, Jianghan University in Wuhan, Hubei Province is taken as an example in this paper, to study the application of engineering practice teaching mode in local universities under credit system.

Jianghan University is a local comprehensive university jointly built by Hubei Province and Wuhan City. On July 3, 2012, the Department of Education officially approved Jianghan University to implement credit system reform, and Jianghan University became one of the first batch of provincial universities who implemented pilot reform of credit system. Since the implementation of credit system management in 2012, due to the limited teaching resources, experiment teaching has been subordinate to theory teaching, with few class hours and insufficient degree of emphasis from 
students. As a weak spot of teaching, experiment teaching has not played its due role, mainly manifested in the following points: (1) there are conflicts between experiment teaching and theory teaching in arrangement; (2) there is coexistence of resource insufficiency and resource waste; (3) there is no sufficient initiative in experiment teaching.

\section{EXPERIMENT TEACHING CREDIT SYSTEM AND IMPLEMENTATION MEASURES}

In order to meet the needs of engineering practice teaching in local universities under credit system, the conception of experiment teaching credit system has been proposed in this paper, to meet the requirements of "people-oriented and individualized talent ability cultivation". After investigation on management situation and experience in experiment teaching of peer universities is conducted, according to the requirements on credit system reform by the Department of Education of Hubei Province, and in combination with the actual situation of the university itself, a conception that is completely beneficial to the cultivation of students' ability has been proposed in this paper, that is, "students fully autonomous" learning plan. Based on full respect for students' right to study independently, the plan allows students to independently choose content of experiment teaching according to their own interests, hobbies, future development direction and curriculum requirements, and to make reasonable learning arrangements according to their time table. Specific content of the plan: according to the requirements of disciplines and courses, the experiment projects will be divided into two categories: compulsory and optional by each experiment center. Compulsory projects are basic key projects, while optional projects are designed to guide students to study according to their own interests, hobbies and future development direction. All projects will be open on normal working days, so that students can make reasonable arrangements according to their own time table. This plan gives students considerable freedom, but students must have a high consciousness. From the perspective of talent cultivation, this plan should be said to be the most advantageous, and it can make full use of experiment teaching resources.

In recent years, the investment on laboratory construction has been increased by this university, instruments and equipments for experiment teaching have been increased, and the technical level of instruments and equipments for experiment teaching have been improved, so that the experiment teaching resources in this university are on a new level. In addition, laboratories are encouraged by the university to actively strengthen cooperation and contact with enterprises, attention has been paid to the introduction of new technologies and new equipments. Through cooperation and co-construction, the functions of university laboratories are enhanced and the features of laboratories are highlighted. While strengthening construction of teaching instruments and equipments in laboratories, a comprehensive layout can be made by the university for experiment centers at all levels, experiment centers of similar disciplines can be arranged relatively centrally, thus to build a brand new platform for the sharing of teaching resources [3]. At present, the experiment teaching instruments, equipments and teaching sites owned by the university have fully met the requirements of the Ministry of Education, providing a good resource platform for the realization of talent cultivation goal and credit reform of experiment teaching.

In order to realize the credit system of experiment teaching, reform must be conducted to original cultivation plan, and reintegration must be conducted to experiment curriculums. In allusion to the conception of experiment credit system, in the process of formulating cultivation plan for professional talents of science and engineering, the proportion of experiment teaching credits in total credits of professional talent cultivation plans should be clearly specified, meantime, from the perspective of "systematically cultivating students' practical ability", necessary integration is conducted to experiments of basic courses and professional courses, credit hours for experiments are increased for curriculums with less credit hours for experiments. According to inner link of courses, the number of verification experiments is reduced, but the number of comprehensive, designing and innovative experiments is increased, so as to strengthen cultivation of students' ability, necessary adjustments are made to experiment projects, the number of comprehensive and designing experiment projects is increased, and teaching content is enriched. For the courses of stratified education, such as the series of courses "Experiments in Mechanics of Materials", the basic experiment projects are unified and are made as compulsory projects. For courses at higher level, the teaching content should be expanded mainly in the way of optional projects.

\section{ADVANTAGES FOR IMPLEMENTING EXPERIMENT TEACHING CREDIT SYSTEM}

If reform of experiment teaching credit system is implemented, the experiment teaching system of the talent cultivation plan in our university can be improved, the proportion of experiment teaching credits is increased, from the perspective of "systematically cultivating students' practical ability", course integration is conducted to experiments, and independent courses are set up for experiments, credits are subdivided into projects, so as to strengthen the cultivation of students' practical abilities, to form a curriculum system for experiment teaching with stratified education from basic education to professional education, and from 
professional education to innovative education, to make experiment teaching and theory teaching rely on each other and complement each other, and to realize the organic unity of theory teaching and experiment teaching in management function. In order to be more conducive to the individualized development of students, a "studentoriented" experiment teaching platform is established. With the application of curricular management mode for experiment teaching where both time and content are open, students are endowed with fuller rights to independent learning, a brand new platform is provided for students' comprehensive quality and ability cultivation, and the enthusiasm of students for selfcultivation is further mobilized. Meantime, with the open experiment teaching, the teaching conflict caused by the lack of resources has been effectively solved.

With the development of society, the constant improvement of conditions of running universities, and the continuous enrichment of credit system practice experience, local engineering universities should conform to this trend, create a credit system management mode that reflects their thoughts and features of running universities, in combination with national conditions and their own situation, keep pace with the time, and make constant improvement; so as to give full play to the role of the teaching management system of credit system in talent cultivation, to cultivate more high-quality engineering and technical persons who meet the needs of society for local economic construction, and to make higher engineering education better serve the development of local economic construction.

\section{CONCLUSION}

Taking Jianghan University in Wuhan city of Hubei Province as a case study, this paper analyses the problems existing in engineering practice teaching in Local Universities under the credit system, puts forward the conception and specific content of engineering experiment teaching credit system, and expounds the advantages of experimental teaching credit system. The research conclusion has strong operability to guide the implementation of engineering practice teaching in the process of credit system implementation in local universities.

\section{ACKNOWLEDGMENTS}

The research fund of this project comes from research topic of educational science planning in Hubei Province. (A Study on Engineering Practice Teaching System under the Credit System of Local Universities).

\section{REFERENCES}

[1] Zhao Bo, Zhao kang, Xu Doping, Exploration and practice of multi level practice teaching system under Credit System in Local Engineering Colleges
[J]. Teaching and educating, 2018, (21), pp.95-96 DOI:10.3969/j.issn.1008-2549.2018.07.039

[2] Jia jiwen, Zhuge Yuping, Research on credit system reform and new practice teaching system construction-Taking College of resources and environment of Shandong Agricultural University as an example $[\mathrm{J}]$. Journal of Hebei Agricultural University (agriculture and Forestry Education Edition), 2016, (02) pp.34-39 (In Chinese) DOI: 10.13320/j.cnki.jauhe.2016.0035

[3] Lu Xiaoyan, Wen Yanxuan, Research on the Countermeasures of engineering practice ability training of engineering students in Local Universities $[\mathrm{J}]$. Experimental technology and management, 2016, (01) pp.13-16 (In Chinese) DOI: 10.16791/j.cnki.sjg.2016.01.004 